\title{
Cross-Disciplinary Service-Learning to Enhance Engineering Identity and Improve Communication Skills
}

\author{
Jennifer Keshwani \\ Assistant Professor and Science Literacy Specialist \\ Department of Biological Systems Engineering \\ University of Nebraska-Lincoln \\ jkeshwani@unl.edu
}

\author{
Krista Adams \\ Assistant Professor \\ Department of Teaching, Learning and \\ Teacher Education \\ University of Nebraska-Lincoln \\ kadams12@unl.edu
}

Abstract - Traditional engineering curricula often do not provide opportunities for students to experience working with non-technical collaborators on real projects. Such interactions may help engineering students develop relevant communication skills. In this study, junior level engineering students collaborated with junior level elementary education students to develop afterschool STEM clubs for elementary children. The study sought to identify the effects of a cross-disciplinary, project-based service-learning experience on: a) the development of a deeper understanding of engineering as a discipline and b) the development of skills necessary to communicate technical information to a non-technical audience. This paper describes the learning outcomes achieved by engaging undergraduate engineering students in cross-disciplinary working relationships. The results suggest that the cross-disciplinary experience affected learning in the knowledge, skills, attitudes and identity of student participants. Student learning was assessed through analysis of questionnaire responses and student reflections. The results also confirmed that simply knowing technical information does not correlate with the ability to communicate that same information. Students reported that they gained experience communicating technical content with non-technical audiences and developed leadership skills. Opportunities to learn communication skills were identified through student comments in course questionnaires and end of the semester focus group discussions.

Index Terms - biomedical engineering, communication, elementary children, K-12 engineering education.

\section{INTRODUCTION}

Professional engineers communicate with audiences representing diverse backgrounds. Engineers report that communication is an important activity that consumes approximately half of their day requiring conversation with both technical and non-technical audiences. ${ }^{1,2}$ While research has shown that communication skills are vital to success in engineering practice, engineering curricula do not adequately prepare engineering students to enter the workforce ready to communicate technical information to non-technical peers. ${ }^{3,4}$ Furthermore, the National Science Foundation has called for an increased focus in expanding professional formation across a variety of contexts including co-curricular activities and community-based learning experiences. ${ }^{5}$ Most engineering student communication experiences involve communicating with other engineering students. The lack of experiences outside the engineering field leave graduates 
International Journal for Service Learning in Engineering,

Humanitarian Engineering and Social Entrepreneurship

Vol. 12, No. 1, pp. 41-61, Spring 2017

ISSN 1555-9033

unprepared to interact with future non-technical clients. ${ }^{4}$ Information synthesis and translation skills are necessary communication skills to share technical information with non-technical audiences and allow engineers to adapt to the variety of interactions encountered throughout their work. ${ }^{1,6}$ Translation skills are vital to turn numbers and graphical information into words in order to make technical information accessible to different types of audiences. ${ }^{1}$ Synthesis of technical information with political and social awareness facilitates communication from a customer needs perspective as well as enhancing a sense of social responsibility. ${ }^{6}$ Such skills are deemed essential by the Accreditation Board of Engineering and Technology (ABET) which emphasizes that engineering students should be capable of communicating effectively, working on multidisciplinary teams, and understanding the broad impacts of their work in global, economic, and social contexts.

\section{Developing Non-TeChNical CoMmunication SKILlS}

The ability to communicate goes beyond the ability to simply put words together to express an idea. Morreale \& Pearson (2008) identified six themes that define the importance of communication skills in the 21 st Century. These themes included: a) 'development of the whole person', b) 'improvement of the educational enterprise', c) 'being a responsible participant in the world, socially and culturally', d) 'succeeding in one's career and in business', e) 'enhancing organizational processes and organizational life', and f) being able to handle 'emerging concerns in the 21 st century' related to health, crime and crisis management. ${ }^{7}$ These themes have been identified by the National Science Foundation as important traits and characteristics of a successful engineering graduate. ${ }^{5}$

Methods to develop communication skills in undergraduate engineers include: a) incorporation of written assignments in engineering courses, b) integrating individual engineering courses with communication courses or even c) integrating communication across the curriculum to engage students in continual practice of communication skills in all engineering coursework. ${ }^{3}$ Communication and writing centers are another opportunity to develop communication skills in undergraduate engineering students. ${ }^{8}$ Often when engineering students have opportunities to work on multidisciplinary teams the represented fields are confined to various engineering disciplines, such as civil engineering students working with chemical engineering students. ${ }^{9}$ However, the students on these interdisciplinary engineering teams still have a similar level of technical understanding, just in different fields. The variety of technical backgrounds present on an interdisciplinary engineering team forces students to be aware of what their teammates are doing. When this interaction is successful, it leads to the development of communication skills and requires students to have an in-depth knowledge of the relevant topics to produce a solution. ${ }^{10}$ Despite these efforts, studies indicate that most engineering graduates fail to truly understand and value cross-disciplinary communication prior to working in industry. ${ }^{11}$

Service-learning projects focused on K-12 educational outreach may achieve many of the same learning outcomes as more traditional engineering projects. For example, the educational realm provides many opportunities to interact with audiences that lack a technical background. ${ }^{12}$ Incorporating a K-12 outreach option for a freshman design class resulted in students reporting learning of teamwork, not to underestimate K-12 students, engineering design process/problem solving, basic engineering/science, and learning from mistakes. ${ }^{13}$ Service-learning in an 
educational setting forces students to work closely with education partners and learners leading to increased engineering student awareness of the human face of engineering. ${ }^{12}$

While multidisciplinary engineering teams have shown promise to improve communication skills between engineering students, students are still lacking opportunities for practicing communication skills with non-technical audiences. ${ }^{3,4}$ The goal of this project was to combine service-learning with cross-disciplinary teamwork to provide opportunities for engineering students to develop communication skills and deepen understanding of the engineering discipline. The objective of this study was to test the hypothesis that partnering undergraduate engineering students with elementary education students to lead afterschool STEM clubs might achieve these goals.

\section{CONCEPTUAL FrAMEWORK}

The conceptual framework for this study focuses on the learning outcomes associated with service-learning experiences in engineering undergraduate programs. Prior work has shown that service-learning experiences allow engineering students to learn a variety of technical and nontechnical skills. ${ }^{14,15}$ The development of teamwork skills, effective communication skills, project management skills and a strengthened work ethic are identified learning outcomes related to service-learning activities. ${ }^{14}$ Bielefeldt et al describes and categorizes the learning objectives achieved through project-based service-learning experiences. These specific learning outcomes are organized into four categories: Knowledge (technical), Skills (design, critical thinking, communication), Attitude (leadership, teamwork, creativity, cultural competence) and Identity (ethics, adaptability, global citizen, self-efficacy, societal context, lifelong learning, and sustainability). ${ }^{15}$ For purposes of this study, cultural competence is an understanding of the beliefs and ways of life of the specific population (undergraduate education students or elementary children). Likewise, societal context is the ability of engineering students to assess the elementary children's perceptions of science and engineering and see their role in improving those perceptions.

\section{LEARNING OBJECTIVES}

In this study, we designed and implemented a cross-disciplinary, project-based service-learning experience to meet two learning objectives for the participating undergraduate engineering students:

1. To develop a deeper understanding of their chosen engineering discipline

2. To develop skills to communicate technical information with non-technical audiences These learning objectives for the project align with some of the learning outcomes described by Bielefeldt et al. achieved through project-based service-learning experiences. Learning Objective 1 corresponds with the Identity category. Undergraduate engineering students will gain a stronger understanding of their role within the engineering community as a result of the projectbased service-learning experience. Learning Objective 2 corresponds with the Skills category. This study provided multiple opportunities for engineering students to practice communicating technical knowledge to non-technical audience and measure the intervention's impact. 


\section{SERVICE-LEARNING ACTIVITY}

The service-learning project involved undergraduate engineering students in a junior-level introduction to biomedical engineering course. This course is required for all students pursuing the biomedical engineering emphasis within biological systems engineering and an elective for other engineering students. This course is offered every fall semester with an enrollment of 4048 students. The engineering course covers a wide-range of biomedical engineering topics including biomaterials, bioinformatics, and imaging. The course objectives state that students would be able to:

- Explain the most prevalent research areas and industrial applications in biomedical engineering

- Identify the types of skills and analytical background required to successfully solve problems in the biomedical engineering fields

- Evaluate the engineering aspects of medical technologies and advancements

- Design a hands-on learning activity to demonstrate a particular biomedical engineering device or principle to a non-scientific audience

The service-learning project served as the final project for the course. The course instructor assigned students to teams with undergraduate elementary education students in a junior-level science methods course to develop and facilitate afterschool STEM clubs at local elementary schools (Figure I). Elementary education majors are required to have two introductory lecture and laboratory science courses along with the science methods course to meet the requirements of the degree. STEM clubs occur in informal environments and involve groups of students meeting regularly to participate in hands-on science, technology, engineering and math activities. Engineering and elementary education undergraduate students worked together to plan and implement hands-on learning activities for the elementary students attending the STEM clubs over six weeks during the second half of a sixteen week semester. Each team identified learning objectives and evaluation methods for their STEM club based on the topic chosen for their club. For example, one of the learning objectives of the Tissue Techs club (Table II) was that the elementary students would understand that cell function can be manipulated through scaffolds. Due to the informal nature of the afterschool STEM clubs, evaluation methods were typically based on student responses and ability to retain information from week to week. Every engineering and education student on the team was responsible for attending at least three days of the STEM club. In addition, each student was responsible for designing and leading the club activities for one day. Leading included identifying hands-on activities for the elementary students to understand key concepts, gathering and preparing supplies, and guiding the elementary students through the activity. Teams decided how to distribute responsibility for developing lesson plans and implementing club activities each day of the STEM club amongst the team members. 
International Journal for Service Learning in Engineering,

Humanitarian Engineering and Social Entrepreneurship

Vol. 12, No. 1, pp. 41-61, Spring 2017

ISSN 1555-9033

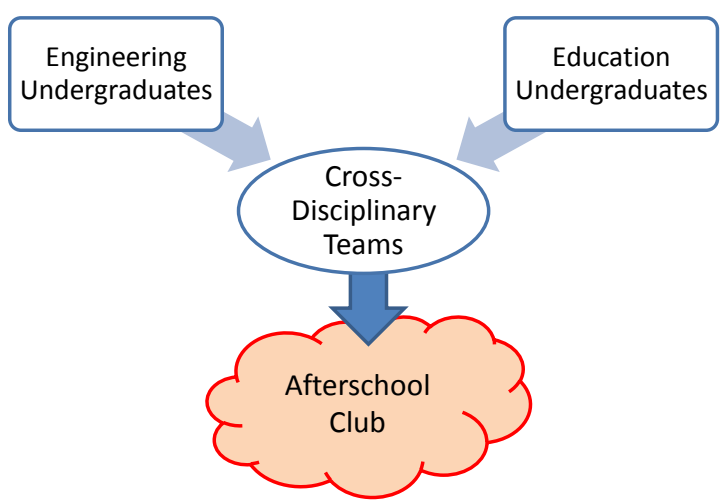

FIGURE I

PROJECT OVERVIEW OF CLUB FORMATION

The course instructors assigned students to groups based on their availability to attend the STEM club on a set day during the week and age preference. A total of 70 students participated; 24 education majors and 46 engineering majors. Each team consisted of two undergraduate elementary education students and four to five undergraduate engineering students resulting in twelve teams. At their initial in-class meeting, the team members discussed their prior formal and informal experiences with science and engineering. The students also participated in a 'draw an engineer' activity to explore stereotypes. The instructors reviewed the project guidelines during the combined meeting (Table I).

TABLE I

DESCRIPTION OF ACTIVITIES DURING FIRST IN-CLASS MEETING OF STEM CLUB TEAMS

\begin{tabular}{ll}
\hline Activity & Details \\
\hline Overview of & Overview: \\
Project: & Design and implement after school STEM activities for elementary children \\
Deliverables and & Deliverables: \\
Expectations & - Plan and facilitate $\sim 6$ week afterschool club with elementary children \\
& - Post weekly reflections in Google+ community \\
& - Submit an overview of afterschool program as a team \\
& - Write a personal reflection on experience
\end{tabular}

Team Assignments Students were assigned to teams based on week day availability to attend STEM club

Artistic Ice Breaker Students drew an engineer individually then shared their drawing with their teammates. The instructors led the students through a discussion of the drawings. For example, many drawings included wild 'Einstein-like' hair or included only male figures. The students then discussed their personal stereotypes regarding engineers.

Get to Know Your Students shared their STEM experiences with their teammates.

Teammates $\quad$ - Were these positive or negative experiences?

- What was the effect of these experiences on your career path?

Define a team $\quad$ Communication plan

contract - How will the team make and implement decisions? 
Students participated in Google+ community groups to facilitate discussions in an environment in which the instructors could monitor and support communications between group members. All students were required to post reflections to questions and respond to group members within these communities. Instructors and team members posted information pertaining to the project on the shared community space. During the second combined in-class meeting, the undergraduate students used class time to work in their teams to identify key learning objectives related to their STEM club topic and plan activities to achieve those learning outcomes. Each team identified and described the unique learning outcomes related to their club in the club description statements (Table II). Prior to this meeting, the engineering students had identified a research article that exemplified biomedical engineering to explain biomedical engineering to their education student teammates. This paper served as a real-world biomedical engineering concept to guide the development of their STEM club.

The intervention described in this paper represents a service-learning experience. According to Furco, service-learning programs 'intention to equally benefit the provider and the recipient of the service as well as to ensure equal focus on both the service being provided and the learning that is occurring. ${ }^{16}$ The undergraduate engineering and education students are the service providers and the elementary students are the service recipients. The described experience intended to provide an opportunity for the elementary children to experience biomedical engineering. The program also intended to help the undergraduate engineering students develop a deeper understanding of the biomedical engineering field and learn communication skills by translating the technical content to both their education student teammates and the elementary children.

\section{STEM Club Topics}

Engineering and education students formed twelve cross-disciplinary teams covering a wide range of science and engineering topics (Figure II). Engineering students identified a research paper within their team that exemplified a specific topic within biomedical engineering. The team used the engineering and science concepts of the identified 'inspiration paper' to guide the development of each STEM club to ensure a strong connection between the STEM club activities and biomedical engineering research. For example, the focus of the Bone Yard club was a paper describing the effect of various bone cements on the mechanical properties of stabilized fractured bones. Accordingly, the team chose activities to help the elementary children understand bone structure and function, how bones break, bone deterioration (such as osteoporosis) and bone stabilization and healing. Table II provides an overview of the STEM club topics and example activities. 
International Journal for Service Learning in Engineering, Humanitarian Engineering and Social Entrepreneurship Vol. 12, No. 1, pp. 41-61, Spring 2017

ISSN 1555-9033
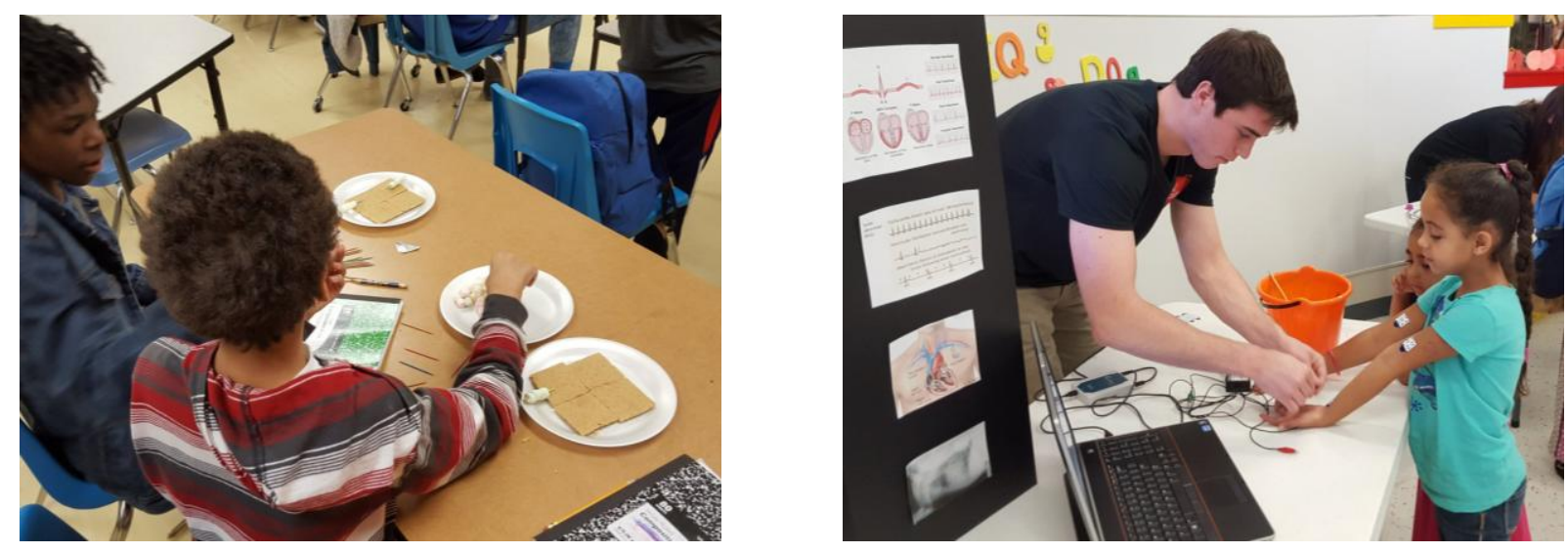

FIGURE II

ELEMENTARY CHILDREN LEARNING ABOUT BIOMEDICAL ENGINEERING THROUGH HEART MODELS IN THE 'OPERATION HEART THROB' CLUB (LEFT) AND ELECTROCARDIOGRAMS IN THE 'ELECTRIFY THE CHILDREN'S MUSEUM' CLUB (RIGHT) 
International Journal for Service Learning in Engineering, Humanitarian Engineering and Social Entrepreneurship

Vol. 12, No. 1, pp. 41-61, Spring 2017

ISSN 1555-9033

\section{TABLE II}

DESCRIPTION OF STEM CLUB NAMES, TOPICS AND INSPIRATION PAPERS

\begin{tabular}{|c|c|c|}
\hline $\begin{array}{l}\text { STEM Club } \\
\text { (grade } \\
\text { level) }\end{array}$ & Topic & Inspiration Paper \\
\hline $\begin{array}{l}\text { Bone Yard } \\
\left(2^{\text {nd }}-3^{\text {rd }}\right. \\
\text { grade })\end{array}$ & $\begin{array}{l}\text { Bone } \\
\text { Function \& } \\
\text { Compositio } \\
\mathrm{n}\end{array}$ & $\begin{array}{l}\text { Tiina Juvonen, Juha-Pekka } \\
\text { Nuutinen, Arto P Koistinen, } \\
\text { Heikki Kroger, and Reijo } \\
\text { Lappalainen. 2015. } \\
\text { Biomechanical Evaluation of } \\
\text { Bone Screw Fixation with a } \\
\text { Novel Bone Cement. 14:74 }\end{array}$ \\
\hline $\begin{array}{l}\text { Clot } \\
\text { Busters } \\
\left(2^{\text {nd }}-3^{\text {rd }}\right. \\
\text { grade) }\end{array}$ & $\begin{array}{l}\text { Blood } \\
\text { Function, } \\
\text { Blood } \\
\text { Types, } \\
\text { Clotting }\end{array}$ & $\begin{array}{l}\text { Tafreshi AS, V Klamroth- } \\
\text { Marganska, S Nussbaumer and } \\
\text { R Riener. 2015. Real Time } \\
\text { Closed-Loop Control Of the } \\
\text { Human Heart Rate and Blood } \\
\text { Pressure. IEEE Trans Biomed } \\
\text { Eng. 62(5);1434-42 }\end{array}$ \\
\hline
\end{tabular}

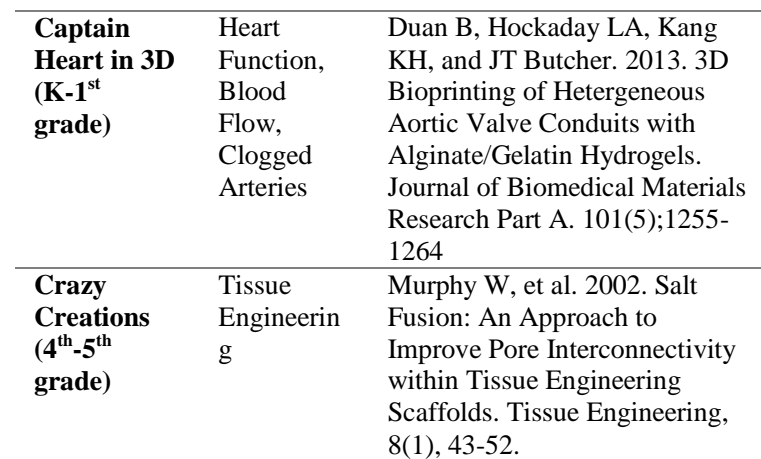

$\begin{array}{ll}\text { Club Description } & \text { Sample } \\ \text { Activity }\end{array}$

Our team is going to explore how the skeletal system

Effect of

affects our everyday lives. We will focus on how to keep osteoporosis on

our bones healthy, what they are made of and how we can bone properties

fix bones with bio-engineering

using sponges,

styrofoam,

cardboard

The primary focus of our club is the circulatory system

with blood being a main topic of interest. We will be

teaching the kids the importance of blood, and why it is

needed for life. Blood types will be discussed, as well as the clotting process of blood. Pumping the blood

Effect of

mixing blood

types model

throughout the body is also a main focus when talking about blood. We will end our club with explaining how the heart pumps and demonstrating this through the use of electrocardiogram.

Our club topic is going to be the heart-its parts and Blood model function in the body, how it works, and diseases with marbles associated with it, building up to the concept of 3D and ping pong printing of artificial heart valves and organs.

balls

using colored

water

bals

\begin{tabular}{|c|c|}
\hline $\begin{array}{l}\text { The focus of Crazy Creations is to narrow down the topic } \\
\text { of tissue engineering into graspable concepts for 4th and } \\
\text { 5th graders. The first concept that the students will learn } \\
\text { is what makes up cells. Secondly, they will learn that to } \\
\text { create a tissue, the cells must align themselves in a pattern } \\
\text { that is natural for that tissue. Lastly, the engineering } \\
\text { concept is how to design a scaffold or mold for the cells } \\
\text { to grow in. This is essential in tissue engineering if an } \\
\text { engineer wants to grow a specific tissue. All of these } \\
\text { topics will build off each other every week, resulting in a } \\
\text { final project of students building their own molds and } \\
\text { growing rock candy on them to represent growing cells to } \\
\text { form tissues like in tissue engineering. }\end{array}$ & $\begin{array}{l}\text { Grow rock } \\
\text { candy on } \\
\text { scaffold } \\
\text { designed by } \\
\text { students }\end{array}$ \\
\hline $\begin{array}{l}\text { The overall focus of our club is looking at all of the } \\
\text { important aspects of DNA. This includes fun, kid-friendly } \\
\text { activities for each lesson plan. These include analyzing } \\
\text { fingerprints, extracting the students' own DNA from their } \\
\text { cheek cells, building candy DNA and using gummy }\end{array}$ & $\begin{array}{l}\text { Fingerprint } \\
\text { analysis as an } \\
\text { analogue to } \\
\text { DNA } \\
\text { fingerprinting }\end{array}$ \\
\hline
\end{tabular}

\begin{tabular}{|c|c|c|c|c|}
\hline $\begin{array}{l}\text { DNA } \\
\text { Detectives } \\
\left(6^{\text {th }} \text { grade }\right)\end{array}$ & $\begin{array}{l}\text { DNA, } \\
\text { Fingerprint } \\
\mathrm{S}\end{array}$ & $\begin{array}{l}\text { Yamunadevi A, Dineshshankar } \\
\text { J, Banu S, and Fathima N. } 2015 . \\
\text { Dermatoglyphic Patterns and } \\
\text { Salivary pH in Subjects with and } \\
\text { without Dental Caries: A Cross- }\end{array}$ & $\begin{array}{l}\text { The overall focus of our club is looking at all of the } \\
\text { important aspects of DNA. This includes fun, kid-friendly } \\
\text { activities for each lesson plan. These include analyzing } \\
\text { fingerprints, extracting the students' own DNA from their } \\
\text { cheek cells, building candy DNA and using gummy }\end{array}$ & $\begin{array}{l}\text { Fingerprint } \\
\text { analysis as an } \\
\text { analogue to } \\
\text { DNA } \\
\text { fingerprinting }\end{array}$ \\
\hline
\end{tabular}

Sectional Study. Journal of worms as chromosomes, and identifying recessive and

Natural Science, Biology, and dominant traits. All of these activities revolve around the

Medicine. 6(2); 295. overarching theme of DNA, and we will structure the lesson plans to build on each other to extend their knowledge of this topic. At the end of the club, the students should have a solid background of DNA obtained by our engaging activities.

\begin{tabular}{|c|c|c|c|c|}
\hline $\begin{array}{l}\text { Electrify } \\
\text { the } \\
\text { Children's } \\
\text { Museum } \\
\text { (all ages) }\end{array}$ & $\begin{array}{l}\text { Electricity } \\
\text { in the Body }\end{array}$ & $\begin{array}{l}\text { Woo SH, Kim TW, Mohy-Ud- } \\
\text { Din Z, Park IY, and Cho JH. } \\
\text { 2011. Small Intestinal Model for } \\
\text { Electrically Propelled Capsule } \\
\text { Endoscopy. Biomedical } \\
\text { Engineering Online. } 10(1) ; 108\end{array}$ & $\begin{array}{l}\text { Electrify the Children's Museum is focusing on electricity } \\
\text { in the body. We are going to help children explore } \\
\text { electricity and relate it back to how it works in their } \\
\text { bodies. We will do this through engaging and hands-on } \\
\text { activities. We are doing this through the use of stations at } \\
\text { the museum. We will show kids the basics of electricity } \\
\text { by teaching them about insulators, conductors, and simple } \\
\text { circuits. We will build on this idea by making batteries } \\
\text { made of everyday objects as well as using apps on the } \\
\text { iPad and doing hands-on circuit making. We will also do } \\
\text { activities based on static electricity. Each activity will be }\end{array}$ & $\begin{array}{l}\text { Circuit } \\
\text { building with } \\
\text { battery and } \\
\text { light bulb }\end{array}$ \\
\hline
\end{tabular}


International Journal for Service Learning in Engineering,

Humanitarian Engineering and Social Entrepreneurship

Vol. 12, No. 1, pp. 41-61, Spring 2017

ISSN 1555-9033

tied back to how that concept in electricity relates back to

the human body. To pull it all together, we will have an

EKG machine for children to use to show directly how

electricity works in the body.

$\begin{array}{lll}\text { Funny } & \text { Bone } & \text { Matsuo T, Kita K, Yonetani Y, } \\ \text { Bones } & \text { Repair, } & \text { Miyamoto S, Yoshikawa H, and } \\ \left(\text { K-2 }^{\text {nd }}\right. & \text { Bone } & \text { Nakata K. 2014. "Bone }\end{array}$

This club will focus on the bone regrowth process. We

will discuss bone structure, injury, and factors which affect the repair process. Activities will include creating paper mache bones, athletic and artistic activities showing these processes, and discussions about how bones stay Depths for Subchondral Bone Repair in Osteochondral Defects of Porcine Knee Joints." Knee Surgical Sports Traumatol Arthrosc. 23:1401-1409.

healthy and strong. Throughout the club meetings, students will work in groups to build a bone model, break the bone, and then repair their bones. These will then be put to the test on the final week of club.

\begin{tabular}{lll}
\hline Molar & Dental & Amaechi, BT, Higham SM, \\
Bears & Hygiene, & Edgar WM. 1998. Use of \\
(4th-5 $^{\text {th }}$ & Tooth & Transverse Microradiography to \\
grade) & Decay, & Quantify Mineral Loss by \\
& Tooth & Erosion in Bovine Enamel. \\
& Protection & Caries Research, 32, 351.
\end{tabular}

The focus of this club is problem solving dental hygiene issues. We are trying to prove why teeth care is important by explaining what causes our teeth to decay and how to prevent it. Our engineering focus is on the tooth itself and creating substances to protect our teeth from cavities or erosion. Each week our students will look at teeth that have been submerged in a substance that is either acidic or basic. The students will observe the teeth every week to see how each tooth is affected.

\begin{tabular}{ll}
\hline Operation & Heart \\
Heart & Function, \\
Throb & Changes in \\
$\left(6^{\text {th }}\right.$ grade $)$ & Heart Rate
\end{tabular}

Weyman A, Patil NP, This club is all about the heart. Throughout the weeks we will measure changes in our heart rate based on when we are scared, excited, relaxed, or physically active. We will then create a yummy heart model to learn more about the functions of the heart and why it is so important. Lastly, we will learn about artificial hearts, cell replication, and eventually build an artificial heart of our own.

\begin{tabular}{lll} 
& & Ahead. PLoS ONE. 9(11):1-8. \\
\hline $\begin{array}{l}\text { Pump It Up } \\
\left(\mathbf{2}^{\text {nd }} \mathbf{- 3} \text { rd }\right.\end{array}$ & Circulatory & Yan, Yongnian, Xiaohong \\
grade) & System, & Wang, Yuqiong Pan, Haixia Liu, \\
& Artificial & Jie Cheng, Zhuo Xiong, Feng \\
& Heart & Lin, Rendong Wu, Renji Zhang, \\
& Valves & and Qingping Lu. "Fabrication
\end{tabular}

The focus of our club is the circulatory system of the human body. We will cover the heart, the blood, the kidneys, the lungs, and finally our engineering topic to pull everything that we have learned together. We have chosen our engineering topic to be an artificial heart valve, and during this final lesson we will go through the engineering problem solving method with the students. Additionally, we will utilize a poster of the circulatory system each lesson to provide continuity between lessons. Constructs with 3D CellAssembly Technique." Biomaterials 26, no. 29 (2005): 5864-871

\begin{tabular}{|c|c|c|c|c|}
\hline $\begin{array}{l}\text { Tissue } \\
\text { Techs } \\
\left(6^{\text {th }} \text { Grade }\right)\end{array}$ & $\begin{array}{l}\text { Manipulati } \\
\text { on of Cell } \\
\text { Growth, } \\
\text { Cell } \\
\text { Function, } \\
\text { Tissue } \\
\text { Engineerin } \\
\text { g }\end{array}$ & $\begin{array}{l}\text { Barron, V., Marghani, K., Shaw, } \\
\text { G., Coleman, C., Hayes, J., } \\
\text { Ansboro, S., Manian, A., } \\
\text { O'Malley, G., Connolly, E., et al. } \\
\text { 2015, "Evaluation of Cartilage } \\
\text { Repair by Mesenchymal Stem } \\
\text { Cells Seeded on a PEOT/PBT } \\
\text { Scaffold in an Osteochondral } \\
\text { Defect," Annals of Biomedical } \\
\text { Engineering, 43, 2069-2082. }\end{array}$ & $\begin{array}{l}\text { The focus of our club is to describe the manipulation of } \\
\text { cell growth for certain things throughout the body. We } \\
\text { will first focus on how cells grow, operate. Then we will } \\
\text { move into how those grow to form tissues. After we have } \\
\text { a basis of tissues and cells we will move into the } \\
\text { engineering behind cell manipulation through scaffolding. } \\
\text { In short, we will talk about fixing issues with tissues. }\end{array}$ & $\begin{array}{l}\text { 3D printing } \\
\text { activity using } \\
\text { Twizzler } \\
\text { Pull'n'peel as } \\
\text { the filament }\end{array}$ \\
\hline Xcyte & $\begin{array}{l}\text { Cells, } \\
\text { Bones, and } \\
\text { Tissue } \\
\text { Engineerin } \\
\mathrm{g}\end{array}$ & $\begin{array}{l}\text { Marolt D, Campos IM, } \\
\text { Bhumiratana S, Koren A, } \\
\text { Petridis P, Zhang G, Spitalnik } \\
\text { PF, Grayson WL, Vunjak- } \\
\text { Novakovic G. 2012. Engineering } \\
\text { bone tissue from human } \\
\text { embryonic stem cells. } \\
\text { Proceedings of the National } \\
\text { Academy of Sciences. } 109(22) ; \\
8705-9\end{array}$ & $\begin{array}{l}\text { The main focus of our club will be to teach students about } \\
\text { the general concept of cells, bones, and tissue } \\
\text { engineering. One of the main things we would like } \\
\text { students to take away is the purpose and importance of } \\
\text { bones in our bodies. The main concepts of each week will } \\
\text { be cells, groups of cells, bones, repairing bones, and } \\
\text { repairing bones with cells. The culminating project will be } \\
\text { using paper to repair our paper maché bones to } \\
\text { demonstrate to students how engineers use bone grafts to } \\
\text { repair bones. }\end{array}$ & $\begin{array}{l}\text { Papier mache } \\
\text { bone building }\end{array}$ \\
\hline
\end{tabular}

\section{METHODS}

In this qualitative study, we sought to identify the shared patterns within the undergraduate engineering students' perceived learning outcomes. Student identification of the desired learning 
outcomes of technical communication skills and understanding of the engineering discipline in their responses to open-ended questions indicated an effect of the implemented learning experience on student learning. We used the Bielefeldt et. al learning outcomes as the conceptual framework to structure the analysis of the data. ${ }^{15}$ We sought to provide a description, interpretation, and understanding of these learning outcomes as defined by the undergraduate engineering students. Specifically, we sought to determine how a project-based service-learning experience supports the development of communication skills and engineering identity of undergraduate engineering students (i.e., pre-service teachers, elementary children).

\section{Participants}

The course instructor invited the undergraduate engineering students to participate in the study at the start of the course. The instructor obtained informed consent for this study (IRB \#20140814591EX) resulting in 77\% of engineering students in the course agreeing to participate. This study uses data from 36 undergraduate engineering students from a Midwestern university. These students are juniors in biological systems engineering major; 14 female, 22 male, and 32 white, 3 of Asian descent, 1 identified as Hispanic (Table III). The cohort of students consenting to participate in the study were consistent with the demographics of the entire class (55\% male; 45\% female; $81 \%$ white; $13 \%$ Asian descent; $6 \%$ identified as Hispanic).

TABLE III

DEMOGRAPHICS OF CONSENTING STUDENTS WITH TOTAL NUMBER AND PERCENTAGE OF CONSENTING COHORT

\begin{tabular}{lll}
\hline Total Students & $\mathbf{N}=\mathbf{3 6}$ & \\
\hline & Male (61\%) & Female (39\%) \\
\hline Caucasian & $19(53 \%)$ & $13(36 \%)$ \\
\hline Hispanic & $1(3 \%)$ & $0(0 \%)$ \\
\hline Asian descent & $2(6 \%)$ & $1(3 \%)$ \\
\hline
\end{tabular}

\section{Data Collection}

Data were collected through two open-response questionnaires administered as part of class assessments and a focus group conducted at the end of the project. We collected data from the engineering students prior to starting the STEM clubs, three weeks into the six-week STEM club experience, and at the end of the semester after the STEM clubs had concluded. We also collected data from the undergraduate education students, which is not included in this study.

\section{Open Response Questionnaires}

Instructors administered two questionnaires at the fifth and twelfth week of a sixteen-week semester course to assess attainment of the learning outcomes based upon the interactions between the engineering students and the education students as well as the elementary children. The first questionnaire asked students to identify the similarities and differences of their prior science and engineering experiences in relation to their undergraduate education and engineering teammates. The second questionnaire, at the twelfth week and three weeks into the afterschool STEM club experience, asked the engineering students to describe what they perceived they 
were learning from their interactions with the education students and/or the elementary children. Each questionnaire was part of a course assessment and took only fifteen minutes to complete.

Questionnaire 1: Describe how your prior science and engineering experiences were similar or different from your TLTE and BSEN teammates.

Questionnaire 2: What (if anything) are you learning from teaching the elementary students or collaborating with the TLTE students?

\section{Focus Groups}

Students participated in a modified focus group interview to determine the impact of the project on their views for communicating technical content to non-technical audiences. The course instructor assigned engineering students to focus groups consisting of three to five students, each representing a different STEM club, in order to collect the shared understandings of the project. Students from each STEM club team were placed in separate focus groups. This allowed each student to have a unique story and perspective to share during the focus group discussion and provided more freedom to comment on their experience with their teammates. Focus group discussions occurred during the final week of the course. All engineering students participated in one of the 13 focus group discussions during a daily class meeting. As we are not looking for a consensus on the questions of the shared experiences, the focus group interviews provided a unique opportunity to observe different perspectives. Focus groups members self-moderated their discussion to encourage the undergraduate engineering students to share their views freely. Focus groups responded to the following questions:

- What did you learn about thinking like a scientist/engineer? What did you learn about communicating science and engineering information to non-engineers?

- How would you define success for your team? In what ways was your team successful?

- What differences in communication did you experience between the elementary education and engineering students?

- What solutions/strategies did you implement to overcome communication difficulties? Were they successful? Why or why not?

- What impact do you feel you and your team had on how future teachers and elementary students perceive engineers?

Prior to the focus group interview, the students were encouraged to share their ideas and opinions about the experiences. The interviews were recorded and transcribed verbatim.

\section{Data Analysis}

The data analysis procedure followed Miles and Huberman grounded theory model in which the conceptual framework defined the themes. ${ }^{17}$ For this study, the thematic codes aligned with those developed by Bielefeldt et al. learning outcomes of project-based service-learning. ${ }^{15}$ Data in the form of student responses were aggregated into a spreadsheet. The coding process involved reading and analyzing each student response to categorize within the thematic codes. After the initial round of coding, the research team engaged in a second round of coding which resulted in identifying an additional code - experiences with science and engineering. We triangulated the data by incorporating multiple data sources (questionnaires and focus group responses) collected at various time points to ensure validity of the conclusions. ${ }^{18}$ 


\section{ANALYSIS OF STUDENT RESPONSES}

Analysis of the data identified several themes in the student responses (Table IV). The presence of a given theme in the collected student work is more informative than the absence of a theme. The absence of a theme simply indicates that the student did not choose to comment on a particular topic in the open-ended responses, which may be due to a lack of awareness of their learning or a lack of vocabulary to explain learning in a certain area. The engineering students described that communicating technical information to a non-technical audience requires a deeper understanding of the material. In addition, engineering students reported general communication skills and opportunities to develop leadership and teamwork skills. The most common responses indicated that the engineering students achieved learning outcomes related to cultural competence and societal context as defined in the Conceptual Framework section. Engineering students also indicated an improved appreciation of the differences between themselves and the education students.

\section{Understanding Technical Knowledge}

A small percentage of the student responses to the second questionnaire focused on the development of technical knowledge because of the service-learning experience (9\%). The engineering students commented that communicating with the elementary education undergraduates or the elementary children required a deep understanding of the technical information. One student reflected in the focus group that,

"I thought it was nice, too, because when you have to explain it to someone else, you actually

have to know what you're talking about. You can't hide behind big words; you have to break it down into simple terms."

The engineering students found the curiosity of the elementary children also pushed them to deepen their explanation of the technical material. One student noted, "Yeah, because kids are always, 'why? Well, why is that? Well, why is that?' so it's kind of a test on your topic."

The elementary children amplified this experience for the engineering students when they connected the presented material to other related topics. The elementary children pushed the engineering students to think beyond their current understanding. One engineering student commented,

"We were telling about how there's different cells, there's cells in the liver, and other muscle cells, and they're all different cells, and he's just like, why are bone cells harder than other cells? And I'm like good question! Not answering you right now! Going to come back to you in like ten years [sic]."

The engineering students realized that explaining technical information to the elementary children required a strong understanding of the material. One student described this realization, stating they were learning "how to properly present material and information in a teaching setting. I feel like I also have a better understanding of tissue engineering since I've had to teach others about it."

\section{Communication Skills}

Students commented that the STEM club experience required strong communication skills (23\% of responses to the second questionnaire) and provided an opportunity to develop these skills. 
International Journal for Service Learning in Engineering,

Humanitarian Engineering and Social Entrepreneurship

Vol. 12, No. 1, pp. 41-61, Spring 2017

ISSN 1555-9033

One engineering student commented, "I am learning how to convey engineering principles in a more simpler [sic] way which ends up helping me in the process."

The focus group discussions at the end of the semester reinforced this theme. The experience provided opportunities for students to learn how to connect with an audience that went beyond standard class presentations. One student noted,

"We realized you can't just sit and talk. They (the elementary children) need to be engaged and you want them to have fun, but you also have to have like a concept behind it. I think linking these two is really difficult because, I think just a feel of biomedical engineering is a rough thing to understand in the first place. Then you know putting that into such simple terms, when the ideas are really pretty complex. It's difficult."

Other students repeated this sentiment. In response to the focus group question related to defining success for their team a student responded, "I define success for my team as being we were able to get the kids to be engaged, because when they're not engaged, you're not going to learn. If you are, you will."

\section{Cultural Competence}

Over half of the engineering students reported increased cultural competence (51\% of responses) as a learning outcome of this experience. The engineering students learned that understanding the culture of their education student teammates and the elementary children was necessary to develop strategies to communicate effectively. One student commented, "I'm also learning that most kids really do think science is cool, they just don't have access to it. Hands on experiences help you get engaged and remember/learn things better." Another student reflected on the importance of being flexible and adapting to situations as they evolve stating,

"I am learning a lot of different things go into teaching. Teaching is something where you have to be very flexible. We can plan lesson plans and have a great vision of how we want the class to go, but things come up and it doesn't always turn out like we planned."

By the end of the semester, the engineering students appreciated the ability of the education students to prepare lesson plans and accommodate the specific needs of their audience (elementary children). The engineering students realized that they would use many of the same skills in their professional careers.

"What I took away from it though honestly is that there isn't that much of a difference between teachers and engineering because engineers utilize a different way to share their education and their knowledge of people. Granted the teachers that we worked with were much better at working with young students and coming up with lesson plans. I think it was more of a symbiotic relationship. I know I definitely learned a lot about teaching from the teachers that went to the (STEM club) with us. I would hope that the impact I had on the elementary students is at least getting them a little more interested in pursuing a career in designing or creating things."

\section{Societal Context}

The second most common student response for learning outcomes related to societal context (43\% of responses). Only a few engineering students noted in the second questionnaire that the elementary students were excited to learn science and engineering. One student commented, "I'm learning that most kids really do think science is cool, which is exciting, they just don't always have access to it." However, many of the engineering students commented on the 
International Journal for Service Learning in Engineering,

Humanitarian Engineering and Social Entrepreneurship

Vol. 12, No. 1, pp. 41-61, Spring 2017

ISSN 1555-9033

difficulty of teaching young students and holding their attention. One student noted that he was learning "that teaching science to really young kids is hard, because they don't have much background knowledge or the attention span to retain or understand very much."

Many engineering students commented that working with young children requires lots of patience. For example, "Kids are a lot of work and you must have a lot of patience. They are eager to learn and that is refreshing."

\section{Leadership \& Teamwork}

A few engineering students commented on the leadership (14\%) and teamwork (14\%) skills they were developing through the project that could be applied in any task. One student noted, "I am learning that preparation and collaboration are the most important aspects to being successful, no matter what the task is." Engineering students also identified the opportunity to work with people outside of the engineering field as a beneficial learning experience. One student commented, 'I'm learning that engineers don't always work with each other, sometimes we have to work with other groups of people to accomplish a goal."

TABLE IV

EXEMPLARY STUDENT RESPONSES TO LEARNING QUESTION AND FOCUS GROUP DISCUSSION RELATED TO STUDENT LEARNING WITH THE FREQUENCY OF EACH THEMATIC CODE

\begin{tabular}{|c|c|c|}
\hline Thematic Code & Exemplary Quotes & $\begin{array}{l}\% \text { of } \\
\text { Responses }\end{array}$ \\
\hline $\begin{array}{l}\text { Communication } \\
\text { skills }\end{array}$ & $\begin{array}{l}\text { - I'm learning how to better interact with the students and how to better communicate with them, } \\
\text { simply by observing the TLTE students when they teach. (Q2) } \\
\text { - I'm learning about how to relate with people of different backgrounds, as well as how to } \\
\text { explain things in multiple ways to help students better understand. (Q2) } \\
\text { - I am learning how to convey engineering principles in a more simpler way which ends up } \\
\text { helping me in the process. (Q2) } \\
\text { - We realized you can't just sit and talk. They (the elementary children) need to be engaged and } \\
\text { you want them to have fun, but you also have to have like a concept behind it. I think linking } \\
\text { these two is really difficult because, I think just a feel of biomedical engineering is a rough } \\
\text { thing to understand in the first place. Then you know putting that into such simple terms, when } \\
\text { the ideas are really pretty complex. It's difficult. (FG) } \\
\text { - I define success for my team as being we were able to get the kids to be engaged, because } \\
\text { when they're not engaged, you're not going to learn. If you are, you will. (FG) }\end{array}$ & $23 \%$ \\
\hline Teamwork & $\begin{array}{l}\text { - I'm learning that engineers don't always work with each other, sometimes we have to work } \\
\text { with other groups of people to accomplish a goal. }(Q 2) \\
\text { - I am learning that preparation and collaboration are the most important aspects to being } \\
\text { successful, no matter what the task is. }(Q 2)\end{array}$ & $14 \%$ \\
\hline
\end{tabular}


International Journal for Service Learning in Engineering,

Humanitarian Engineering and Social Entrepreneurship

Vol. 12, No. 1, pp. 41-61, Spring 2017

ISSN 1555-9033

- I am learning that preparation and collaboration are the most important aspects to being successful, no matter what the task is. (Q2)

- Being very prepared is important. Especially with middle school students, they'll notice right away if you're not completely on your game. (Q2)

Cultural

competence

- Patience! I have to understand that these students have been in school all day and may be a little burnt out on learning. Teaching is rewarding: Despite the fact that there are some bratty kids there are also students who really enjoy seeing us and that is a good feeling! (Q2)

- I learned it is hard to keep a young students attention for too long without being enthusiastic about what you are teaching. If you seem interested and excited about the subject you are teaching them they will be as well. (Q2)

- I'm also learning that most kids really do think science is cool, which is exciting; they just don't always have access to it. Hands on experiences help you get engaged and remember/learn things better. (Q2)

- I am learning a lot of different things go into teaching. Teaching is something where you have to be very flexible. We can plan lesson plans and have a great vision of how we want the class to go, but things come up and it doesn't always turn out like we planned. (Q2)

- What I took away from it though honestly is that there isn't that much of a difference between teachers and engineering because engineers utilize a different way to share their education and their knowledge of people. Granted the teachers that we worked with were much better at working with young students and coming up with lesson plans. I think it was more of a symbiotic relationship. I know I definitely learned a lot about teaching from the teachers that went to the (STEM club) with us. I would hope that the impact I had on the elementary students is at least getting them a little more interested in pursuing a career in designing or creating things. (FG)

\begin{tabular}{|c|c|c|}
\hline Adaptability & $\begin{array}{l}\text { - Teaching is something where you have to be very flexible. We can plan lesson plans and have } \\
\text { a great vision of how we want the class to go, but things come up and it doesn't always turn } \\
\text { out like we planned. }(Q 2)\end{array}$ & $3 \%$ \\
\hline Societal context & $\begin{array}{l}\text { - Patience! I have to understand that these students have been in school all day and may be a } \\
\text { little burnt out on learning. Teaching is rewarding. Despite the fact that there are some bratty } \\
\text { kids there are also students who really enjoy seeing us and that is a good feeling! (Q2) } \\
\text { - Students are afraid of science and engineering for some reason. However, once we start an } \\
\text { activity they really have a lot of fun. (Q2) } \\
\text { - I'm learning how excited kids are about engineering topics. I overestimated how much they } \\
\text { know about engineering topics, so I've also learned how much there is to teach them about } \\
\text { engineering. I'm also learning all the things you have to take into account to teach grade } \\
\text { school kids. (Q2) } \\
\text { - I'm also learning that most kids really do think science is cool, which is exciting; they just } \\
\text { don't always have access to it. Hands on experiences help you get engaged and } \\
\text { remember/learn things better. (Q2) } \\
\text { - Kids are a lot of work \& you must have a lot of patience. They are eager to learn \& that is } \\
\text { refreshing. (Q2) } \\
\text { - Our kids are super bright and they retain information week from week. This really surprised } \\
\text { me initially (Q2). } \\
\text { - That teaching science to really young kids is hard, because they don't have much background } \\
\text { knowledge or the attention span to retain or understand very much. (Q2) }\end{array}$ & $43 \%$ \\
\hline Global citizen & $\begin{array}{l}\text { - I'm learning that engineers don't always work with each other, sometimes we have to work } \\
\text { with other groups of people to accomplish a goal. It's also nice to see the kids learn } \\
\text { engineering at such an early age. (Q2) }\end{array}$ & $9 \%$ \\
\hline
\end{tabular}

The thematic codes of Design, Critical Thinking, Creativity, Ethics, Lifelong Learning, Self-Efficacy, and Sustainability are not included in the table due to their absence in the student responses. Sources of the quotes are indicated at the end of each line as from Questionnaire $2(\mathrm{Q} 2)$ or the end of the semester focus group (FG) transcripts. 
Perceptions and Experiences with Science and Engineering

Responses to the first questionnaire reflected differences in the prior experiences of students related to science and engineering (Table V). Over half of the engineering students (57\%) answered the prompt 'Describe how your prior science and engineering experiences were similar or different from your TLTE [education] and BSEN [engineering] teammates' by stating that both groups had similar experiences. One student commented, "We were all similar in that we were exposed to science at a somewhat young age and all taught the basics throughout middle/high school." However, many of the students (49\%) noticed that the engineering students remembered enjoying science and engineering experiences more than the education students did. Student responses often alluded to both the prior similar experiences and differing levels of enjoyment. For example, one student commented, "I would say we all had fairly similar science exposure although my fellow BSEN [engineering] teammates and I enjoyed them more than our TLTE [education] teammate." Another student stated, "Compared to the engineers my experiences were very similar. As for my TLTE [education] teammates we were different in that she was not a big fan of the sciences." 
International Journal for Service Learning in Engineering,

Humanitarian Engineering and Social Entrepreneurship

Vol. 12, No. 1, pp. 41-61, Spring 2017

ISSN 1555-9033

\section{TABLE V}

EXEMPLARY STUDENT RESPONSES TO PERCEPTIONS AND EXPERIENCES OF STUDENTS WITH SCIENCE AND ENGINEERING SORTED BY EACH THEMATIC CODE AND FREQUENCY OF RESPONSES

\begin{tabular}{|c|c|c|c|}
\hline \multicolumn{2}{|r|}{ Thematic Code } & Exemplary Quotes & \multirow{2}{*}{\begin{tabular}{|l|}
$\begin{array}{l}\text { \% of } \\
\text { Responses }\end{array}$ \\
$57 \%$
\end{tabular}} \\
\hline \multirow{3}{*}{ 帝 } & Experiences & $\begin{array}{l}\text { - Like my fellow TLTE and BSEN teammates, I participated in science fairs early on } \\
\text { in school. } \\
\text { - We were all similar in that we were exposed to science at a somewhat young age } \\
\text { and all taught the basics throughout middle/high school. } \\
\text { - We all had very similar backgrounds during elementary school. } \\
\text { - Many of us had been exposed to what we considered engineering at a young age } \\
\text { whether through toys or classroom activities. }\end{array}$ & \\
\hline & $\begin{array}{l}\text { Lack of } \\
\text { engineering } \\
\text { experiences }\end{array}$ & $\begin{array}{l}\text { - I never had much of an exposure to engineering in school where I learned about } \\
\text { different engineering topics and fields, similar to my other teammates. } \\
\text { - As for engineering, I would say most of us had no exposure really except for two } \\
\text { BSEN who loved playing with Legos. }\end{array}$ & $14 \%$ \\
\hline & Enjoyment & $\begin{array}{l}\text { - A lot of my group has had positive experiences learning about science topics in } \\
\text { primary school. } \\
\text { - I was not surprised that all BSEN students have enjoyed science from a young age. } \\
\text { I was surprised that the TLTE students also enjoyed science when younger. The } \\
\text { difference in career paths was partially because science is not mandated like math } \\
\text { and reading, so students don't take something they don't have to. }\end{array}$ & $14 \%$ \\
\hline \multirow{3}{*}{ } & Experiences & $\begin{array}{l}\text { - My BSEN teammates have had more in depth classes and are more comfortable } \\
\text { digging into the details of the sciences. My TLTE teammates on the other hand have } \\
\text { not had those classes and seem less willing to try and understand the information. } \\
\text { - My prior experience was relatively similar to that of my BSEN teammates in that } \\
\text { we all had significant experience w/ science in high school... The teachers in our } \\
\text { group had less scientific experience because she didn't really enjoy the subject so } \\
\text { she avoided it as much as possible. } \\
\text { - It seems that my BSEN team members and I had more experiences or better } \\
\text { experiences with math than the TLTE members. We also had more chances to dive } \\
\text { deeper into the science and engineering than the TLTE members which probably } \\
\text { gave us a fuller experience in those areas. }\end{array}$ & $26 \%$ \\
\hline & Enjoyment & $\begin{array}{l}\text { - We were different in how we enjoyed and pursued a science intensive major. My } \\
\text { BSEN teammates and I all said we enjoyed our science courses and took courses } \\
\text { related to it while TLTE teammates mostly said they didn't enjoy their experiences. } \\
\text { - Compared to the engineers my experiences were very similar. As for my TLTE } \\
\text { teammates we were different in that she was not a big fan of the sciences. } \\
\text { - The teachers in my group, on a whole, didn't have the best experiences w/ science. } \\
\text { The other engineers enjoyed both math and science and that's why they're } \\
\text { engineers. } \\
\text { - I would say we all had fairly similar science exposure, although my fellow BSEN } \\
\text { teammates \& I enjoyed them more than our TLTE teammate. }\end{array}$ & $46 \%$ \\
\hline & $\begin{array}{l}\text { Independent } \\
\text { Activities }\end{array}$ & $\begin{array}{l}\text { - The difference was that the BSEN students had a lot of hands-on engineering and } \\
\text { science experiences (i.e. experiments, working on cars, etc.). The TLTE students on } \\
\text { the other hand enjoyed their in-class experiences more. They enjoyed reading } \\
\text { textbooks and listening to lectures. } \\
\text { - However, my BSEN teammates tended to have done more experiments or } \\
\text { engineering projects outside of school, which is also something I did. }\end{array}$ & $20 \%$ \\
\hline
\end{tabular}




\section{DISCUSSION}

This paper sought to identify the effects of a cross-disciplinary project-based service-learning experience on two learning objectives: developing a deeper understanding of the engineering discipline by undergraduate engineering students (Identity category) and developing skills to communicate technical information with a non-technical audience (Skills category). The results reveal that the learning objectives achieved by this experience aligned with all four of the learning outcome categories described by Bielefeldt et. al. ${ }^{15}$

\section{Technical}

The development of technical skills was not a focus of this experience. However, the engineering students had to recall technical information to support the content of the STEM clubs. Often the elementary children would challenge the scope of the engineering student's knowledge. The majority of the technical knowledge gained through the STEM club experience better aligns with the core content of the education students. The engineering and education students learned how to prepare lesson plans for the STEM club activities and maintain order in a classroom of children. While not immediately apparent, these technical skills are transferable to situations in professional engineering careers. For example, the skills associated with preparing a lesson plan are similar to planning a business meeting. In planning a meeting, a future engineer will need to assess the current understanding of their audience and determine appropriate outcomes for the meeting. Based on these outcomes, the engineering students are prepared to identify appropriate discussion questions or meeting activities.

\section{Skills}

The engineering students had a variety of opportunities to practice communication skills through the project-based service-learning experience. Communication across a variety of contexts was integral to planning and facilitating the STEM clubs. The experience provided an opportunity to practice aligning technical content to meet the needs of an audience.

It is worth noting that none of the collected student work mentioned the development of design or critical thinking skills because of the STEM club experience. The development of the STEM clubs followed a process similar to engineering design. The student teams were given a problem (create and implement a STEM club for elementary children) with criteria and constraints (time limitations, topic must relate to biomedical engineering, etc.). The teams brainstormed and selected activity ideas to meet the learning objectives similar to a design solution. The student teams evaluated the success of the STEM club at the end of the semester. Despite the alignment with the engineering design process, the engineering students did not recognize the design aspect of the STEM clubs. This may have been due to the non-technical nature of the problem of designing an afterschool STEM club.

\section{Attitude}

While the intent of the cross-disciplinary activity was to achieve learning outcomes classified as Skills and Identity, the majority of student responses reflected the Attitude theme. Students recalled opportunities to practice leadership skills in meaningful ways through the afterschool STEM clubs. Several students mentioned the importance of planning and preparation for success. Students developed cultural competence to guide their communications with both their 
teammates and the elementary students participating in the afterschool STEM clubs. While these skills relate to general communication skills, the awareness of the engineering students to capture the attention of the elementary students by being fun and engaging while breaking down complex ideas to be relevant to both their teammates and the elementary students aligns with the cultural competence of the Attitude category.

Creativity was the only skill in this category not mentioned in the student responses. As evidenced in Table II, nearly every STEM club team developed creative activities to teach their children about biomedical engineering. For example, the Tissue Techs club designed an activity using Twizzler Pull'n'Peel candy to allow elementary children to pretend they were a 3D printer. The candy represented the plastic extruded from the printer that the children used to build artifacts. Through this activity, the children were able to understand the limitations and capabilities of the additive process of 3D printing. Despite these creative solutions to achieve complex student learning outcomes, the engineering students did not identify the activity as a creative experience.

\section{Identity}

The engineering students developed a stronger understanding of the engineering discipline through the STEM club experience. Translating complex topics to the elementary education students and the elementary children pushed the engineering students to deepen their understanding and highlighted gaps in their knowledge.

Engineering students gained an understanding of the societal context of both the elementary education students and the elementary children attending the afterschool STEM clubs. The engineering students correctly identified that they will not likely encounter these specific populations in the engineering profession. However, students will encounter other non-technical audiences such as clients and management in the engineering profession. The skills developed in identifying the unique contexts of non-technical audiences and meeting their unique needs are transferrable to these future interactions.

Three skills within the Identity category were absent in the collected student work: ethics, lifelong learning, and sustainability. Due to the nature of the STEM clubs, we did not anticipate outcomes related to these areas.

There are limitations to using the development of afterschool STEM clubs as an engineering project-based service-learning project. The instructors guided students to connect the STEM club topics to biomedical engineering. However, students struggled to see the development of the project as an engineering activity. In prior years, the instructors allowed students to choose any biomedical engineering topic as the focus of the STEM club. Often the resulting club topics would be limited to standard elementary science activities such as states of matter or chemical reactions. As a result, students would fail to connect the clubs to biomedical engineering. Requiring students to choose the STEM club topic with respect to a primary literature article helped strengthen this connection.

\section{CONCLUSIONS}

This cross-disciplinary, project-based service-learning experience provided opportunities for engineering students to achieve the desired learning objectives of deepening their understanding 
International Journal for Service Learning in Engineering, Humanitarian Engineering and Social Entrepreneurship Vol. 12, No. 1, pp. 41-61, Spring 2017

ISSN 1555-9033

of the engineering discipline and developing skills to communicate technical information with a non-technical audience. The results of this study validate the hypothesis that undergraduate engineering students would develop communication skills and a deeper understanding of their field through collaborations with elementary education students to lead afterschool STEM clubs. While the experience did not provide opportunities to practice engineering professional skills, such as design and critical thinking, students reported learning communication and leadership skills, and gained experience understanding the unique societal and cultural contexts of nontechnical audiences. Learning experiences that combine cross-disciplinary teamwork with service-learning through K-12 outreach activities may help meet the need to expand professional formation of engineers to prepare engineers for the workforce.

\section{ACKNOWLEDGMENT}

The authors would like to thank the 21 st Century Community Learning Center Coordinators for working with our students and accommodating their schedules.

\section{REFERENCES}

1. Darling, Ann L, and Deanna P Dannels. 2003. "Practicing Engineers Talk about the Importance of Talk: A Report on the Role of Oral Communication in the Workplace." Communication Education 1-16.

2. Vest, David, Marilee Long, and Thad Anderson. 1996. "Electrical Engineers' Perceptions of Communication Training and Their Recommendations for Curricular Change: Results of a National Survey." IEEE Transactions on Professional Communication 38-42.

3. Reave, Laura. 2004. "Technical Communication Instruction in Engineering Schools: A Survey of Top-Ranked U.S. and Canadian Programs." Journal of Business and Technical Communication 452-490.

4. Auzenne, A Michele, Adrian T Hanson, Ricardo B Jacquez, and Chris Burnham. 2006. "Understanding Engineering Design as an Argumentative Strategy." Science, Engineering \& Technology Education Annual Conference. Las Cruces, NM.

5. National Science Foundation. 2016. "PFE: Research Initiation in Engineering Formation." National Science Foundation. October 31. Accessed December 12, 2016. https://www.nsf.gov/pubs/2017/nsf17514/nsf17514.pdf.

6. Cox, Monica F, Osman Cekic, Benjamin Ahn, and Jiabin Zhu. 2012. "Engineering Professionals' Expectations of Undergraduate Engineering Students." Leadership and Management in Engineering 60-70.

7. Morreale, Sherwyn P, and Judy C Pearson. 2008. "Why Communication Education is Important: The Centrality of the Discipline in the 21st Century." Communication Education 224-240.

8. Ford, Julie Dyke, and Linda Ann Riley. 2003. "Integrating Communication and Engineering Education: A Look at Curricula, Courses, and Support Systems." Journal of Engineering Education 325-328.

9. Newell, James A, and Doug D Cleary. 2004. "Using an Undergraduate Materials Research Project to Foster Multidisciplinary Teaming Skills." Journal of STEM Education 18-23.

10. Cutright, Teresa J, Edward Evans, and Justin S Brantner. 2014. "Building an Undergraduate STEM Team Using Team-Based Learning Leading to the Production of a Storyboard Appropriate for Elementary Students." Journal of Science Education Technology 344-354. 
11. Lappalainen, Pia. 2009. "Communication as Part of the Engineering Skills Set." European Journal of Engineering Education 123-129.

12. Mokhtar, Wael A. 2014. "An Integrated Service Project for Junior and Senior Students." International Journal for Innovation Education and Research 93-108.

13. Bottomley, Laura J, Mary C Robbins, and Elizabeth Parry. 2003. "Service Learning in the Freshman Engineering Course." ASEE Annual Conference. 3453.

14. Litchfield, Kaitlin, Amy Javernick-Will, and Andrew Maul. 2016. "Technical and Professional Skills of Engineers Involved and Not Involved in Engineering Service." Journal of Engineering Education 70-92.

15. Bielefeldt, Angela R, Kurtis G Paterson, and Christopher W Swan. 2010. "Measuring the Value Added from Service Learning in Project-Based Engineering Education." International Journal of Engineering Education 535-546.

16. Furco, Andrew. 1996. "Service-Learning: A Balanced Approach to Experiential Education." Expanding Boundaries: Service and Learning 2-6.

17. Miles, Matthew B, and A Michael Huberman. 1994. Qualitative Data Analysis: A Sourcebook. Beverly Hills: Sage Publications.

18. Teddlie, Charles, and Abbas Tashakkori. 2009. Foundations of Mixed Methods Research: Integrating Quantitative and Qualitative Approaches in the Social and Behavioral Sciences. Thousand Oaks, CA: SAGE Publishing. 